\title{
Shifting consumers' sustainable behavior in the hospitality industry
}

\author{
I Wayan Edi Arsawan ${ }^{1}$, Viktor Koval ${ }^{2}$, Ni Putu Santi Suryantini³ ${ }^{3}$, and Yuriy Polyezhayev ${ }^{4}$ \\ ${ }^{1}$ Politeknik Negeri Bali, Jl. Raya Uluwatu No.45, Jimbaran, Kec. Kuta Sel., Kabupaten Badung, Bali 80361, Indonesia \\ ${ }^{2}$ Odessa Institute of Trade and Economics of Kyiv National University of Trade and Economics, 6 Inglezi Str., Odesa, 65056, Ukraine \\ ${ }^{3}$ Universitas Udayana, Jl. Raya Kampus Unud No.2013, Jimbaran, Kec. Kuta Sel., Kabupaten Badung, Bali 80361, Indonesia \\ ${ }^{4}$ National University “Zaporizhzhia Polytechnic”, 64 Zhukovsky Str., Zaporizhzhia, 69063, Ukraine
}

\begin{abstract}
Although research on hotel booking intention has been carried out in the last decade, the research that reveals the role of hotel reservation information through online consumer reviews in the millennial generation is still very rare. This study aims to determine the factors of online consumer reviews that affect hotel booking intentions for the millennial generation in Bali, Indonesia. This study uses a quantitative approach by distributing questionnaires to 385 respondents through a non-probability sampling technique, namely purposive sampling. The data analysis technique of this research is a multiple linear regression analysis processed using the SPSS 25.0 program. The results reveal that usefulness, timeline, and comprehensiveness have a significant effect on hotel booking intentions. Meanwhile, the volume of online reviews, the positive valence of online reviews, and the negative valence of online reviews are not significant for hotel booking intentions. The research findings reveal the characteristics of the millennial generation which are in line with the theory of reason action that they have their views in making decisions. The research implications are discussed in the paper.
\end{abstract}

\section{Problem statement}

Tourists traveling to Indonesia during 2019 were mostly young tourists aged 15-24 (24.2\%), 25-34 years (15.3), and 35-44 years (18.8) (Central Bureau of Statistics) 2018) [1]. The increasing number of young tourists from year to year is the largest market segmentation for the hotel and tourism industry so it is important to understand the character and needs of these millennial travelers.

In making buying and selling transactions, the millennial generation has an interesting pattern. Where to purchase after reading reviews by searching for information through social media, e-commerce sites, or online travel agents. Due to the nature of product experience, online reviews have become an increasingly popular source of information in travel planning and have a major influence on consumer purchasing decisions, especially in hotel bookings [2].

Online reviews provide information about goods or services that are different geographically and have experience with the goods or services in question [3]. Consumers prefer to read reviews and recommendations from experienced customers before buying a product or service that significantly influences consumer buying decisions [4].

Online surveys are central in tourism, tourism sustainability in turn affects the environment and economies of countries, taking into account the needs of consumers and sustainable changes in consumer behaviour. Environmental factors in choosing a hotel do not play a key role in contrast to basic factors (such as location, price, etc.), but the development of green tourism over time should change this situation.

Due to the intangible nature of tourism products, prospective tourists buy hotel rooms that have a high level of risk and uncertainty [5-6]. Although the information guidance provided on the website is very limited, the role of information in decision making has not been studied much. Thus, hotels are expected to show uniqueness that is characteristic of increasing competitive advantage [7].

Before deciding to book a hotel room, consumers first seek information about the desired hotel either through family, friends, travel agents, or the Internet to help make decisions [8]. In the tourism industry, tourists rely on information whether it is obtained online or offline.

This study will try to close the existing research gap, namely, first, although several studies have identified the individual role of information cues, such as scarcity, popularity, and consumer ratings [9], research investigating the effect of different information is still scarce. Therefore, it is important to check which information clues (i.e. usefulness, timeline, volume, positive valence, negative valence, and comprehensiveness) have a significant influence on potential traveler booking intentions.

\footnotetext{
* Corresponding author: wayanediarsawan@pnb.ac.id
} 
The second gap is for tourists, searching for information via the Internet both from the official hotel website and online consumer review (OCRs) provides a lot of information. However, the online reviews that are presented have various characteristics, how online reviews are measured, both in quality and quantity, and how detailed and specific the information is uploaded on the website. This leaves tourists with many confusing perspectives [10]. As a result, hoteliers and travel agents are challenged to provide comprehensive facilities on online consumer reviews (OCRs), such as categorizing relevant OCRs to help consumers get the right information to make decisions.

The third gap is in the field of study relating to Indonesian millennial consumers, which is currently the largest target hotel market. Millennial consumer hotel reservation intentions have not been well researched, especially those influenced by online consumer reviews factors. Although millennial consumers are a very attractive consumer segment, not much research has been conducted on millennial consumer hotel booking behavior caused by online consumer reviews.

Based on this, it is important to conduct this research, which is to find out more details about which factors or attributes of OCRs can affect booking interest [11], especially consumers from the millennial generation, get a better experience when they look for relevant information about hotels that want to be visited and make it easier for them to make decisions. The effect is that the hotel manager or travel agent can implement a better marketing strategy, especially related to OCRs.

Online consumer review as a form of e-WOM have become an important factor in shaping consumer behavior. Through online reviews from other consumers, sharing review platforms can influence consumer buying interest $[12,13]$. Online reviews have a positive and significant impact on hotel booking intentions so online reviews must be managed as a strategic communication channel [14].

\section{Research methods}

This research was conducted in Bali Province, Indonesia with respondents are the millennial generation, the generation aged 20 to 39 years, or those born in 19802000 [1]. The sample was determined using nonprobability sampling, namely purposive sampling, that is the millennial generation, having or planning to book hotels, have read online reviews.

The reason for choosing the millennial generation is because it has a strong potential to read online consumer reviews first before booking a hotel according to the theory of experts, is a productive age group (15 - 64 years) to book high hotels, read online hotel reviews and conduct hotel booking. The data collection technique of this research is through distributing questionnaires with a Likert scale of 1-5, which were analyzed by multiple linear regression analysis.

The methods of questionnaires of hotel services customers and analysis are used in the research and they show that consumer resilience don not reflect the primary importance for OCRs, since most online reviews do not contain information stability and do not influence hotel booking, unlike other factors that are detailed in the article.

\section{Literature review}

The usefulness of an online review refers to the quality or level of usefulness of an online review. Park and Lee [15] suggested that usefulness is how far consumers believe online reviews will facilitate their purchasing decision-making process. An online review will have a useful value for consumers if it contains additional information that contains information that is relevant, useful, neutral in nature, and comes from the perspective of consumers Abdullah et al. [16]. One of the reasons travelers look for information about hotels online is to plan their trip, so they need precise information that can describe hotel conditions based on previous consumer experiences. This is an organizational competitive advantage through the dissemination of appropriate information [7].

$H 1=$ Usefulness of online review has a significant positive effect on hotel booking intention

Timeline refers to "whether the message is current, timely and up to date" Cheung et al. [17]. During the process of searching for information, consumers may be faced with relevant information but in large quantities and originate from different times. Thus, the website must be updated on an ongoing basis to provide useful information for consumers/users. The results also reveal that in the current e-commerce era, the most recent product reviews will get more attention from users [18]. Consumers will follow the latest news developments from hotels of interest through OCR or hotel social media., the latest information will describe the current condition of a hotel which can affect the purchase decision [19].

$H 2$ = Timeline of online review has a significant positive effect on hotel booking intentions

Review volume refers to the number of reviews that a product or service gets from reviewers of Davis and Khazanci [20]. The number of reviews given by reviewers is another attribute of the word of mouth because it displays reviews from different reviewers. The higher the volume of reviews, both positive and negative reviews, in the context of online communication, this will attract the attention of information seekers which can then increase product awareness [21].

H3 = Volume of online reviews has a significant positive effect on hotel booking intentions

Online positive reviews are a form of response that usually can be in the form of recommendations from consumers for their satisfaction with the services they received previously. Previous research has highlighted the importance of customer recommendations in the context of service delivery, as it has been illustrated empirically that one recommendation can be sufficient to 
convince someone to try a recommended service provider [22]. Reviews with a very positive rating will lead to significant growth in product sales (Clemons et al. (2006) [23]. Consumer purchase intentions increase if the quality of reviews is maintained. The more quantity of positive reviews, the more likely it is to influence consumers to book hotels [24].

$\mathrm{H} 4$ = Positive valence of online review has a significant positive effect on hotel booking intentions

Several researchers have analyzed the negative impact of online reviews on hotel bookings and found that a large number of negative reviews on a hotel lead to negative attitudes towards hotel bookings [25]. Negative reviews are generally written in response to consumer dissatisfaction which can harm business [26] because it is considered to be more dangerous than complaints and complaints, which are largely invisible. goods [15]. The results of other studies reveal that negative online reviews can reduce consumer attitudes towards hotels that are in demand, although online negative reviews will be able to increase their consumers' awareness of that hotel [25].

$H 5=$ Negative valence of online review has a significant negative effect on hotel booking intentions

The completeness features in the online review have a relationship with the online review recommendation itself and are an advantage in being able to measure how detailed and complete a review is [17]. For consumers, especially the first When going to make a purchase, it certainly requires complete information about the product or service to be used and as a basis for deciding whether to purchase or not, which means that the detailed and comprehensive features of online reviews have a significant contribution to consumer hotel booking intention [27] Another study stated that online review completeness is one of the most effective elements of online posting in terms of the extent to which people are willing to accept and adopt online reviews, as well as the factors that drive adoption [17]. H6 = Comprehensiveness of online review has a significant positive effect on hotel booking intentions.

\section{Results of research}

Before distributing the questionnaires, the first 30 respondents tested the validity and reliability. After that, the questionnaire was distributed via google forms, and distributed via email, social media by including a cover letter about this research. From 385 data obtained for approximately 9 months (September 2019- May 2020), information was obtained that as many as $63 \%$ of respondents were women and $37 \%$ of respondents were men. The age category ranges from $20-24$ years $(43.4 \%)$, 25-29 (36.4\%), 30-34 years (16.9\%) and 35-39 (3.4\%). Besides, 3-star hotels dominate the respondents' choices for the category of hotels that are preferred and often chosen when traveling with a percentage of $43.6 \%$, 4star hotels (29.8) and 5-star hotels (26.6) (see Table 1).
Table 1. Demographic of respondents $(n=385)$

\begin{tabular}{|l|c|c|}
\hline \multicolumn{1}{|c|}{ Criteria } & Amount & Percentage \\
\hline Gender & & \\
\hline Male & 143 & 37 \\
\hline Female & 242 & 63 \\
\hline Ages & & \\
\hline $20-24$ & 167 & 43,4 \\
\hline $25-29$ & 140 & 36,4 \\
\hline $30-34$ & 65 & 16,9 \\
\hline $35-39$ & 13 & 3,4 \\
\hline Hotel Classification & & \\
\hline $3^{*}$ & 168 & 43,6 \\
\hline $4 *$ & 115 & 29,8 \\
\hline $5 *$ & 102 & 26,6 \\
\hline
\end{tabular}

\subsection{Classic assumption test}

The normality test is carried out to find out whether the data to be used is normally distributed or not. The results of the normality test are seen from the Asymp value. Sig. (2-tailed) of 0.761 , which exceeds the value of the level of significance of 0.05 , so it can be concluded that the data in this study were normally distributed.

Tabel 2. Heteroscedasticity and multicollinearity test.

\begin{tabular}{|l|c|c|c|c|}
\hline \multicolumn{1}{|c|}{ Model } & Sig. & Tolerance & VIF & Remarks \\
\hline \multicolumn{3}{|c|}{ Constant) } \\
\hline $\begin{array}{l}\text { Usefulness of online review } \\
\left(\mathrm{X}_{1}\right)\end{array}$ & 0,138 & 0,877 & 1,140 & Free \\
\hline $\begin{array}{l}\text { Timeline of online review } \\
\left(\mathrm{X}_{2}\right)\end{array}$ & 0,965 & 0,930 & 1,075 & Free \\
\hline $\begin{array}{l}\text { Volume of online review } \\
\left(\mathrm{X}_{3}\right)\end{array}$ & 0,862 & 0,920 & 1,087 & Free \\
\hline $\begin{array}{l}\text { Positive valence of online } \\
\text { review }\left(\mathrm{X}_{4}\right)\end{array}$ & 0,773 & 0,942 & 1,062 & Free \\
\hline $\begin{array}{l}\text { Negative valence of online } \\
\text { review }\left(\mathrm{X}_{5}\right)\end{array}$ & 0,142 & 0,907 & 1,102 & Free \\
\hline $\begin{array}{l}\text { Comprehensiveness of } \\
\text { online review }\left(\mathrm{X}_{6}\right)\end{array}$ & 0,074 & 0,942 & 1,061 & Free \\
\hline
\end{tabular}

A heteroscedasticity test is performed to test whether the regression model has inequality of variants from the residuals of one observation to another (see Table 2). The heteroscedasticity test was tested using the Glejser test, namely by regressing the absolute residual value on the independent variable. The significance value of the variable usefulness $(0,138)$, timeline $(0,965)$, volume $(0,862)$, positive valence $(0,773)$, negative valence $(0,142)$, and comprehensiveness $(0,074)$ is greater than 0.05 . This means that there is no influence between the independent variables on absolute residuals so that the model made does not contain symptoms of heteroscedasticity.

Multicollinearity (see Table 2) between independent variables does not occur if they have a VIF of less than 10 and a Tolerance number of more than 0.1 . The results show that the tolerance values for the usefulness variables $(1.140 / 0.877)$, timeline $(1.075 / 0.930)$, volume (1.087/0.920), positive valence $(1.062 / 0.942)$, negative valence (1.102/0.907), and comprehensiveness $(1.061 / 0.942)$ are greater than 0.1 and have a VIF value 
that is smaller than 10 , so it can be said that there are no multicollinearity symptoms in this study.

\subsection{Multiple regression analysis}

Multiple regression analysis is used to examine the effect of two or more independent variables on the dependent variable. The independent variables in this study are the variable usefulness $\left(\mathrm{X}_{1}\right)$, timeline $\left(\mathrm{X}_{2}\right)$, volume $\left(\mathrm{X}_{3}\right)$, positive valence $\left(\mathrm{X}_{4}\right)$, negative valence $\left(\mathrm{X}_{5}\right)$, and comprehensiveness $\left(\mathrm{X}_{6}\right)$. Meanwhile, the dependent variable is hotel booking intentions. Based on the results of the multiple regression test in Table 1, the multiple linear regression equation in this study is as follows.

$$
\begin{aligned}
& Y=0,796+0,272 X_{1}+0,183 X_{2}-0,068 X_{3}+ \\
& 0,096 X_{4}-0,055 X_{5}+0,189 X_{6}+e
\end{aligned}
$$

\begin{tabular}{|c|c|c|c|c|c|}
\hline \multirow{2}{*}{ Model } & \multicolumn{2}{|c|}{ Unstandardized Coefficients } & \multirow{2}{*}{\begin{tabular}{|c|} 
Standardized Coefficients \\
Beta
\end{tabular}} & \multirow{2}{*}{$\mathbf{t}$} & \multirow{2}{*}{ Sig. } \\
\hline & B & Std. Error & & & \\
\hline \begin{tabular}{|l|l|}
1 & (Constant) \\
\end{tabular} & 0,796 & 0,439 & & 1,820 & 0,072 \\
\hline Usefulness[X $\left.\mathrm{X}_{1}\right]$ & 0,272 & 0,057 & 0,246 & 4,904 & 0,000 \\
\hline Timeline $\left[\mathrm{X}_{2}\right]$ & 0,183 & 0,055 & 0,166 & 3,402 & 0,001 \\
\hline Volume $\left[\mathrm{X}_{3}\right]$ & $-0,068$ & 0,062 & $-0,058$ & $-1,128$ & 0,261 \\
\hline Positive Valence $\left[\mathrm{X}_{4}\right]$ & 0,096 & 0,048 & 0,097 & 1,955 & 0,054 \\
\hline Negative Valence $\left[\mathrm{X}_{5}\right]$ & $-0,055$ & 0,046 & $-0,062$ & $-1,209$ & 0,229 \\
\hline Comprehensiveness $\left[\mathrm{X}_{6}\right]$ & 0,189 & 0,053 & 0,178 & 3,719 & 0,000 \\
\hline $\begin{array}{l}\text { R Square } \\
\text { Adjusted R Square } \\
\text { F value } \\
\text { Sig. F }\end{array}$ & $\begin{array}{r}0,158 \\
0,145 \\
11,688 \\
0,000\end{array}$ & & & & \\
\hline
\end{tabular}

Table 3. Multiple regression analysis.

In Table 3 information is presented that the adjusted $\mathrm{R}$ Square value is 0.145 which means that $14.5 \%$ of hotel booking intentions variations can be explained by the variables usefulness, timeline, volume, positive valence, negative valence, and comprehensiveness, while the remaining $85.5 \%$ is explained by other factors beyond this research model. The significance value of $F$ is 0.000 . The significance value is lower than the value of $\alpha=0.05$. This means that the research model involving usefulness, timeline, volume, positive valence, negative valence, and comprehensiveness variables is feasible to estimate hotel booking intentions variables.

\subsection{Hypotheses testing}

Hypothesis testing as presented in Table 3 explains that the usefulness variable of the Sig. 0.000 is smaller than $\alpha=0.05$ with a positive regression coefficient of 0.272 . This shows that the usefulness variable has a significant positive effect on hotel booking intentions so that $\mathrm{H}_{1}$ is accepted. This shows that the higher the usefulness of online reviews, the more interest in hotel bookings will be. The usefulness of online review will be considered important and useful if the information submitted in the OCR is related to the hotel, the content is reliable, neutral and reflects the reviewer's heart, according to experience, presents useful information, is related to the hotel, is not confusing and impartial. The results of this study are in line with the research [27, 28] that the usefulness of online reviews has a positive effect on hotel booking intentions.

The timeline variable is Sig. 0.001 is smaller than $\alpha=0.05$ with a positive coefficient of 0.183 . This shows that the timeline variable has a significant positive effect on hotel booking intentions so that $\mathrm{H}_{2}$ is accepted. This shows that the more up to date an OCRs will increase interest in hotel bookings. This condition illustrates that consumers are very concerned about uploading reviews, loading the latest information, following the latest news developments that affect purchasing decisions [19]. This is in line with what was stated by Jindal and Liu [18] who found that in the current e-commerce era, the latest online reviews will get more attention from other consumers. Consumers will get information about the development of hotel services through OCRs, which has been around for a long time. As for the company, this will help build the company's reputation in terms of responsiveness when answering consumer reviews. The results of this study support the research of Zhao et al. [27] that the timeline has a significant effect on consumer interest in hotel booking intentions.

The volume variable $\left(\mathrm{X}_{3}\right)$ is the Sig. 0.261 is greater than $\alpha=0.05$ but the negative coefficient value is -0.068 . This shows that the volume variable has a negative and insignificant effect on hotel booking intentions, so $\mathrm{H}_{3}$ is rejected. This means that the number of online consumer reviews (OCRs) cannot increase interest in hotel bookings. Respondents assumed that the amount of OCRs does not guarantee the information that is informative, original, and following consumer expectations. On the other hand, consumers often only read a portion of reviews before deciding to purchase because they are more focused on new reviews [30]. Another factor is opinion leadership where consumers do not care or pay much attention to volume but rather trust the opinions of influential people [20]. The findings of this study confirm the characteristics of the millennial generation who are more easily influenced by the opinions of influential people such as the public figure.

The positive valence variable is Sig. 0.054 is greater than $\alpha=0.05$ and the regression coefficient is positive at 0.096. This shows that the positive variable has a positive but insignificant effect on hotel booking intentions, so $\mathrm{H}_{4}$ is rejected. Positive comments written 
by reviewers are a response to the satisfaction of the service received but unable to attract online bookings. The results of the study contradict the results of the research of Tsao et al. [3] who found that reading positive comments has a strong influence on booking intentions.

This condition can occur because positive valence expresses subjective opinions so that consumers do not pay attention to the number of positive reviews. Besides that, the number of positive online consumer reviews that is too much can also cause doubts to consumers about the credibility of the online consumer reviews. This may be caused by companies that pay reviewers to write reviews according to the company's wishes to help their sales [30], where the valence of these reviews can be adjusted according to the seller's needs. The results of this study refute the results of the study by Tsao et al. [3] that positive reviews are the most influential in determining interests and attitudes to decide [34].

The negative valence variable is Sig. 0.229 is greater than $\alpha=0.05$ and the negative regression coefficient value is -0.055 . This shows that the negative valence variable has no significant effect on hotel booking intention, so $\mathrm{H}_{5}$ is rejected. This shows that negative valence does not affect hotel booking intentions. Negative reviews are a response to dissatisfaction with the service perceived by consumers and have a negative impact on business interests [26] so that these negative comments can be handled properly, it will increase room bookings/hotel room sales [32-35].

The variable comprehensiveness value is Sig. 0.000 is smaller than $\alpha=0.05$ and the regression coefficient value is positive 0.189 so that H6 is accepted. This shows that the more complete and detailed the contents of an online consumer review (OCR) will increase interest in hotel bookings. When consumers are unfamiliar with a product/service, consumers will need more detailed and specific information to help them make decisions [32].

Consumers are more interested in a complete and detailed OCR which contains information such as the experience of staying, reviews of the hotel's superior facilities, information about the location, prices, and services provided by the hotel based on the customer's perspective. Consumer behavior should be aimed at achieving more sustainable results and achieving sustainable consumer behavior, which includes simplification of consumption [31-33]. This means that the assessment from the reader side is an important indicator in decision making [2] because it is proven that comprehensiveness of online reviews is an important attribute among the attributes of OCR that can influence consumer purchase interest $[17,27]$.

\section{Conclusion}

Theoretically, the results of this study add to the body of knowledge in the hotel booking intentions literature while closing the research gap. First, that the model formed from the variable usefulness, timeline, volume, positive valence, negative valence, and comprehensiveness contributed significantly to online booking intention in industrial hotels.

The results of this study also succeeded in closing the second gap in how hotel websites and online travel agents paid high attention to the quantity, quality and detail of information so as to present comprehensive and not confusing information. This information provides an important impact on how consumers take attitudes and determine decisions for hotel bookings. Last, to closing the third gap, the results of the present study also provide insight that the behavior of the millennial generation is unique, a characteristic that is aware of technology and tends to follow leadership opinions from influential figures. The results of the study illustrate that OCR has a significant effect on the online booking intentions of hotels. Overall, our findings show that the perspective of the millennial generation is important in considering hotel booking intentions.

Given the complexity of the online environment, several variables may influence the intentions to purchase online. The theory of reason action (TRA) provides a structure for the model adopted in this study and helps to focus on the main antecedents of online ordering intentions. TRA is one of the most widely used theories for predicting attitude-behavior relationships and has been widely adopted in tourism studies. The concept underlying TRA is that individuals evaluate the implications of their reasoned actions before they decide to engage in certain behaviors. In particular, this theory proposes that behavioral intentions is the main element responsible for consumer behavior.

Managerially, managers can carry out strategies at two levels, namely, at the individual level, by increasing knowledge sharing between units that manage the website so that it becomes more innovative, creative, up to date and interesting. managerial is by implementing:

1) adding the usefulness voting feature of existing online reviews, so that readers can judge which reviews they think to help their information search process;

2) use review categories by entering the time sequence category to display the latest reviews from reviewers;

3) hotel managers or travel agents are advised not only to focus on a large number of reviews but also pay attention to the quality and valence (positive or negative) of online reviews;

4) pay more attention to negative reviews or complaints from consumers;

5) provide information in the form of a summary from written reviews, such as graphic information that shows the percentage of reviewers who said they were satisfied with hotel services and other information.

Because millennial consumers tend to rely on categorical information because it is simple and easy to understand, the effect is that organizations have a culture of innovation to be able to maintain competitive advantage through the continuous system and website updates. 


\section{References}

1. Central Bureau of Statistics. National Tourist Statistics. Jakarta.

(2019). https://www.bps.go.id/pressrelease/2019/08/01/1615 /jumlah-kunjungan-wisman-ke-indonesia-juni-2019mencapai-1-45-juta-kunjungan-.html. Accessed 21 Mar 2021

2. I. C. C. Chan, L. W. Lam, C. W. C. Chow, L. H. N. Fong, R. Law, International Journal of Hospitality Management 66, $54 \quad$ (2017). doi:10.1016/j.ijhm.2017.06.007

3. W.-C. Tsao, M.-T. Hsieh, L.-W. Shih, T. M. Y. Lin, International Journal of Hospitality Management 46, 99 (2015). doi:10.1016/j.ijhm.2015.01.008

4. A. Bataineh, International Journal of Marketing Studies 7 (2015). doi:10.5539/ijms.v7n1p126

5. Y. Reisinger, J. Kandampully, C. Mok, B. Sparks, Unique characteristics of tourism, hospitality, and leisure services. Service quality management in hospitality, tourism and leisure 1(1), 15-47 (2001)

6. E. Sirakaya, A. G. Woodside, Tourism Management 26, 815 (2005). doi:10.1016/j.tourman.2004.05.004

7. I. W.E. Arsawan, I. Sanjaya, I. Putra, I. Sukarta, Journal of Physics: Conference Series 953 (2018)

8. B. A. Sparks, V. Browning, Tourism Management 32, 1310 (2011). doi:10.1016/j.tourman.2010.12.011

9. K. Park, J. Ha, J.-Y. Park, Journal of Hospitality Marketing \& Management 26, 627-643 (2017). doi:10.1080/19368623.2017.1284631

10. I. C. C. Chan, L. W. Lam, C. W. C. Chow, L. H. N. Fong, R. Law, International Journal of Hospitality Management 66, 54-65 (2017). doi:10.1016/j.ijhm.2017.06.007

11. W.-C. Tsao, M.-T. Hsieh, L.-W. Shih, T. M. Y. Lin, International Journal of Hospitality Management 46, 99-111 (2015). doi:10.1016/j.ijhm.2015.01.008

12. C. P. Furner, R. Zinko, Z. Zhu. JSTP 26, 788 (2016). doi:10.1108/JSTP-01-2015-0022

13. C.-L. Hsu, L.-C. Yu, K.-C. Chang, Computers in Human Behavior 69, 335-346 (2017)

14. J. Bulchand-Gidumal, S. Melián-González, B. González Lopez-Valcarcel, International Journal of Hospitality Management 35, 44-47 (2013). doi:10.1016/j.ijhm.2013.05.003

15. C. Park, T. M. Lee, Journal of Interactive Marketing 23, 332-340 (2009). doi:10.1016/j.intmar.2009.07.001

16. D. Abdullah, K. Jayaraman, D. N. Shariff, K. Anuar Bahari, N. Md Nor, The effects of perceived interactivity, perceived ease of use and perceived usefulness on online hotel booking intention: A conceptual framework. International Academic Research Journal of Social Science 3, 16-23 (2017)

17. C. M. K. Cheung, M. K. O. Lee, N. Rabjohn, Internet Research 18, 229-247 (2008)
18. N. Jindal, L. Bing, Opinion spam and analysis, in Proceedings of the 2008 international conference on web search and data mining, pp. 219-230 (2008)

19. Y. Liu, Journal of Marketing 70, $74-89$ (2006). doi:10.1509/jmkg.70.3.074

20. A. Davis, D. Khazanchi, Electronic Markets 18, 130-141 (2008)

21. H. Etzion, A. Neveen, Pump up the volume? Examining the relationship between number of online reviews and sales: Is more necessarily better?, in ICIS 2007 Proceedings (2007)

22. D. D. Gremler, Word-of-Mouth about Service Providers: an Illustration of Theory Development in Marketing, in American Marketing Association. Winter Conference (1994).

23. E. K. Clemons, G. G. Gao, L. M. Hitt, Journal of Management Information Systems 23, 149-176 (2006)

24. D.-H. Park, J. Lee, I. Han, International Journal of Electronic Commerce 11, 125-148 (2007). doi:10.2753/JEC1086-4415110405

25. I. E. Vermeulen, D. Seegers, Tourism Management 30, 123-127 (2009). doi:10.1016/j.tourman.2008.04.008

26. D. Charlett, R. Garland, N. Marr, How damaging is negative word of mouth. Marketing Bulletin 6, 4250 (1995)

27. X. (Roy) Zhao, L. Wang, X. Guo, R. Law, Int J Contemp Hospitality Mngt 27, 1343 (2015). doi:10.1108/IJCHM-12-2013-0542

28. C., Yubo, J. Xie, Online consumer review: Word-ofmouth as a new element of marketing communication mix. Management science 54, 477491 (2008).

29. BrightLocal, Local Consumer Review Survey 2016. https://www.brightlocal.com (2016). Accessed 21 Mar 2107

30. X. Li, L. M. Hitt, Z. J. Zhang, Journal of Management Information Systems 27, 9-42 (2011). doi:10.2753/MIS0742-1222270401

31. K. Kostetska, N. Khumarova, Y. Umanska, N. Shmygol, V. Koval, Management Systems in Production Engineering 28 (2), 15-22 (2020)

32. Q. Ye, R. Law, B. Gu, International Journal of Hospitality Management 28, 180 (2009)

33. R. B. Money, M. C. Gilly, J. L. Graham, Journal of $\begin{array}{llll}\text { Marketing } & \text { 62, } & \text { 76-87 }\end{array}$ doi:10.1177/002224299806200406

34. I.W.E.Arsawan, V.Koval, I. Rajiani, N.W. Rustiarini, W.G. Supartha, N.P.S. Suryantini, International Journal of Productivity and Performance Management (2020 in press). doi:10.1108/IJPPM-04-2020-0192

35. N. Purnawirawan, M. Eisend, P. De Pelsmacker, N. Dens, Journal of Interactive Marketing 31, 17-27 (2015). doi:10.1016/j.intmar.2015.05.001 